\title{
Preliminary Analysis of the Possibility of Preparing PVB/IF-WS Composites. Effect of Nanoparticles Addition on Thermal and Rheological Behavior of PVB
}

\author{
Danica Simić ${ }^{1)}$ \\ Dušica Stojanović ${ }^{2)}$ \\ Mirjana Dimic ${ }^{1)}$ \\ Ljubica Totovski ${ }^{1)}$ \\ Saša Brzić ${ }^{1)}$ \\ Petar Uskoković ${ }^{2)}$ \\ Radoslav Aleksić ${ }^{2}$
}

\begin{abstract}
A possibility of using inorganic fullerene-like tungsten disulfide, IF-WS ${ }_{2}$, nanoparticles as a filler in poly (vinyl butyral), PVB, for improving its thermal and rheological properties is examined. PVB is a thermoplastic polymer with excellent properties, widely used: in ballistic protection, for protection of safety glass, in metal primers and coatings, temporary binders. Two different molecular weights of PVB were previously examined in this research: Mowital B60H and B75H. Both grades of PVB were dissolved in different solvents: ethanol and 2-propanol. Thin films were prepared by solvent casting technique. The glass transition temperature ( $\left.T_{g}\right)$ of the tested samples was determined using differential scanning calorimetry (DSC), at three different heating rates $\left(5^{\circ} \mathrm{C} / \mathrm{min}, 10^{\circ} \mathrm{C} / \mathrm{min}\right.$ and $\left.20^{\circ} \mathrm{C} / \mathrm{min}\right)$. After choosing a solvent and $\mathrm{PVB}$ grade, IF-WS $\mathrm{S}_{2}$ nanoparticles were added to PVB solutions and dispersed by ultrasonic irradiation. Compatibility, i.e. interaction of IF-WS $\mathbf{W}_{2}$ with the dissolved PVB was examined by microcalorimetry method. The nanoparticles dispersion and deagglomeration in matrix of PVB was analyzed by scanning electron microscope (SEM). The effect of IF-WS ${ }_{2}$ on rheological properties of the chosen samples has been examined using Dynamic Mechanical Thermal Analysis (DMTA), observing storage modulus, loss modulus and the loss factor as functions of temperature for the tested composites.
\end{abstract}

Key words: fullerene particles, tungsten disulfide, nanoparticles, thermoplastic polymer, poly(vinyl butyral), composite materials, rheological properties, thermal properties, scanning calorimetry, compatibility.

\section{Introduction}

$\mathrm{I}^{\mathrm{N}}$ NORGANIC fullerene-like nanoparticles of transition-metal dichalogenides, having spherical closed structure, are well known for their excellent mechanical properties. They are used for a wide range of applications, including aerospace and automotive technology, in different mechanisms for load bearing and release, for corrosion protection, and as solid lubricants [1]. Tungsten disulfide, as one among them, is extensively studied for its ability to control wetting, adhesion, lubrication on surfaces and interfaces, and is recognized as promising filler of the composite materials. Inorganic fullerene-like tungsten disulfide nanoparticles $\left(\mathrm{IF}-\mathrm{WS}_{2}\right)$ are thermally stable and compatible with various systems, so incorporating them into a proper matrix may lead to composites with new properties. It is shown that with low IF-WS ${ }_{2}$ additions into a polymer matrix the composites exhibited improved thermal, rheological, and mechanical properties, compared to their neat polymers [2]. Different thermoplastic polymers or thermosetting resins are examined in combination with $\mathrm{WS}_{2}$ as reinforcement, for the purposes of development of new advanced composites with improved mechanical properties, for high technology applications [1-7]. Multilayer tungsten disulfide has shown outstanding shock resistance properties superior to those of even carbon nanotubes $[3,4,8]$.
In this paper a possibility of using IF-WS ${ }_{2}$ nanoparticles as a filler in poly (vinyl butyral), PVB, for improving its thermal and rheological properties is examined. PVB is a thermoplastic polymer with excellent properties, widely used: for protection of safety glass, in metal primers and different types of protective coatings, temporary binders, and nowadays it is widely used in ballistic protection [9-11]. PVB is a tough polymer with excellent flexibility, broad compatibility with modifying resins and additives, non-toxic and low odor, good adhesion to many substrates and strong binding, impact resistance, good tensile strength and elasticity, freezing and aging resistance, well soluble in alcohols and many other organic solvents, fast drying, fast solvent release and low solvent retention, good film formation, transparent and colorless [9].

\section{Materials and experimental procedure}

\section{Preparation of composite material samples}

Two different molecular weights of the fine-grained white powder PVB (Mowital, Kuraray GMBH) were examined in this research: Mowital B60H and B75H. PVB in content of 10 wt.\% was dissolved in two solvents: ethanol and 2-propanol.

\footnotetext{
1) Military Technical Institute (VTI), Ratka Resanovića 1, 11132 Belgrade, SERBIA

2) University of Belgrade, Faculty of Technology and Metalurgy, Karnegijeva 4, 11020 Belgrade, SERBIA

Correspondence to: Danica Simić; e-mail: simic_danica@yahoo.com
} 
Thin films were prepared and the glass transition temperature $\left(T_{g}\right)$ of the tested samples was determined using differential scanning calorimetry (DSC), at three different heating rates $\left(5^{\circ} \mathrm{C} / \mathrm{min}, 10^{\circ} \mathrm{C} / \mathrm{min}\right.$ and $\left.20^{\circ} \mathrm{C} / \mathrm{min}\right)$. Homogenization and complete dissolving of PVB was done on the magnetic stirrer during 24 hours at room temperature. Inorganic fullerene-like tungsten disulfide nanoparticles (IF-WS 2 , NanoLub ${ }^{\mathrm{TM}}, d_{25^{\circ} \mathrm{C}} \sim$ $7.5 \mathrm{~g} / \mathrm{cm}^{3}$ ) were added into the PVB/EtOH solution in content of $1 \mathrm{wt} . \%$ and $2 \mathrm{wt} . \%$, regarding the total mass of PVB in the sample. Dispersion and particle deagglomeration was achieved by ultrasonic irradiation during $30 \mathrm{~min}$ (Sonic Vibra Cell VCX 750, $19 \mathrm{~mm}$ Ti horn, $20 \mathrm{kHz}$ ) at room temperature. $\mathrm{PVB} / \mathrm{WS}_{2}$ nanocomposites were prepared by the solventcasting technique. After homogenization, mixtures were directly poured into the previously prepared flat-bottom dishes and left for the solvents to evaporate. Then the dishes with the samples were placed into a heating oven over the night, and into a vacuum heating oven during one more night, so the prepared samples turned into the solid thin films after the complete amount of solvents evaporated.

\section{Differential Scanning Calorimetry}

The glass transition temperature $\left(T_{g}\right)$ of the prepared thin film samples was determined using DSC Q20 (TA Instruments), with data acquisition program Universal V4.7A. The measurements were performed under a nitrogen flow of $50 \mathrm{ml} / \mathrm{min}$ in the temperature range from $20^{\circ} \mathrm{C}$ to $100^{\circ} \mathrm{C}$. The samples were first heated from 20 to $100^{\circ} \mathrm{C}$ at a rate of 5,10 and $20^{\circ} \mathrm{C} / \mathrm{min}$, then cooled down to $20^{\circ} \mathrm{C}$ at the same rate, and then heated once again. $T_{g}$ from the first and the second heating, at the three heating rates, were compared and analyzed.

\section{Microcalorimetry analysis method}

All spontaneous chemical and physical processes are associated with heat effects. Monitoring the flow of heat may be used to estimate interactions between different materials in touch, or study their compatibility. This method is widely accepted in laboratories that do the testing of chemical compatibility of explosives and polymers and other materials using heat flow calorimeter, which is described in standard STANAG 4147 [13]. However, microcalorimetry may as well be used to observe the degree of interactions between any different materials.

In this research, these tests were performed using heat flow calorimeter LKB Bioactivity Monitor 2277. Samples (nanoparticles, PVB powder, PVB dissolved in ethanol and 2propanol, and the mixtures of nanoparticles with pure or dissolved PVB) were heated for 456 hours at $75^{\circ} \mathrm{C}$. The released heat in time is compared with reference value, which represents the sum of the heat released when these materials are heated separately. Based on the results of measurements, the energy released per unit of mass for examined materials is determined, separately and for mixtures thereof. The coefficient $D$ is calculated, as a relative measure of interaction between the tested materials, using equation (1):

$$
D=2 M /(E+S)
$$

Where:

$M$ - heat generation of the mixture, $\mathrm{J} / \mathrm{g}$;

$E$ - heat generation of the nanoparticles, $\mathrm{J} / \mathrm{g}$;

$S$ - heat generation of the polymer / solution, $\mathrm{J} / \mathrm{g}$.

\section{SEM/EDS analysis}

The quality of the nanoparticles dispersion and deagglomeration in PVB matrix was analyzed by scanning electron microscope (SEM), JEOL JSM-6610LV connected with energy dispersive X-ray spectrometer (EDS), OXFORD $X$-Max with Aztec software. The samples were carbon coated and investigated under the voltage of $10-15 \mathrm{kV}$. EDS analysis is carried out to observe the morphology and the elemental composition of the samples.

\section{Dynamic mechanical thermal analysis}

The effect of IF-WS 2 on rheological and viscoelastic properties of the chosen samples has been examined using Dynamic Mechanical Thermal Analysis (DMTA). Dynamic mechanical analysis of the investigated samples was performed in a torsion deformation mode using the Modular Compact Rheometer MCR-302 (Anton Paar GmbH) equipped with standard fixtures (SRF12) for rectangular bars, temperature chamber (CTD-620) having high temperature stability $( \pm 0.1)$ [12]. The rectangular samples of thin film composites had dimensions $54 \mathrm{~mm} \times 10 \mathrm{~mm} \times(0.3-0.4) \mathrm{mm}$. DMTA tests have included strain amplitude sweep tests, in order to determine the linear viscoelastic range (LVR) of the tested samples.

Strain sweeps are oscillatory tests performed at variable amplitudes, while keeping the frequency at constant value (also, the measuring temperature). These tests were performed at $T=20^{\circ} \mathrm{C}$, while shear strain, $\gamma$ was varied from $0.001 \%$ up to $10 \%$, i.e., from 0.00001 up to 0.1 , with 41 equidistant values on a linear scale. Frequency was held constant at $6.28 \mathrm{rads}^{-1}$.

In order to use DMTA technique to accurately determine thermorheological properties of a material, it must be deformed at amplitudes that remain within the linear viscoelastic region (LVR). Within LVR, the viscoelastic response of the polymer is independent of the magnitude of deformation. As a general rule, this region must be determined for every type of polymeric material by DMTA amplitude sweep tests, in which a frequency is fixed and the strain amplitude is incrementally increased. The strain sweep test is the first step in dynamic mechanical analysis and it is always performed prior to a frequency sweep test in order to determine an appropriate strain level for temperature and frequency sweeps. The temperature ramp test involves measurements of the storage and loss moduli and the loss factor over a specified temperature range at constant strain (or stress) amplitude and constant frequency. The temperature ramp test was carried out in a ramp fashion. In the temperature range from $20^{\circ} \mathrm{C}$ to $120^{\circ} \mathrm{C}$ the rheological parameters of the viscoelastic properties of the prepared composites were observed: the storage modulus $\left(G^{\prime}\right)$, loss modulus $\left(G^{\prime \prime}\right)$ as a function of the temperature for the studied composites, and the loss factor, $\tan (\delta)=G^{\prime \prime} / G^{\prime}$. The heating rate was $5^{\circ} \mathrm{C} / \mathrm{min}$ and the single frequency point of $1 \mathrm{~Hz}$ was chosen. The glass transition temperature $\left(T_{\mathrm{g}}\right)$, determined by the dynamic mechanical measurements, was estimated as the temperature at which the loss factor, $\tan (\delta)$ reached its maximum value.

\section{Results and discussion}

\section{DSC results}

For PVB grades $\mathrm{B} 60 \mathrm{H}$ and $\mathrm{B} 75 \mathrm{H}$, for all the three heating rates, registered $T_{g}$ values, presented in Tables 1 and 2, are much more uniform for the second heating, while for the first heating there is a significant difference between the obtained results. This is the most pronounced for PVB dissolved in 2propanol and for pure PVB powder. 
It may be observed that higher $T_{g}$ values are obtained in $2^{\text {nd }}$ heating, for all the three speeds of heating. For the first heating, at the heating rate of $20^{\circ} \mathrm{C} / \mathrm{min}$, the highest $T_{g}$ is recorded for both solvents, for both PVB grades. In the second heating, PVB dissolved in 2-propanol has the highest registered $T_{g}$ for heating rate $5^{\circ} \mathrm{C} / \mathrm{min}$, while pure PVB powder and PVB dissolved in ethanol have highest $\mathrm{T}_{g}$ observed for the heating rate of $20^{\circ} \mathrm{C} / \mathrm{min}$ (Fig.1).

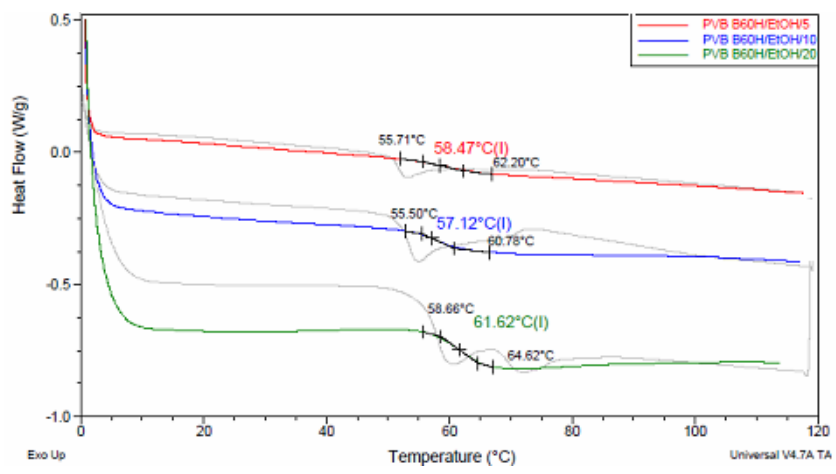

Figure 1. DSC at heating rates 5,10 and $20^{\circ} \mathrm{C} / \mathrm{min}$

Table 1. Tg of PVB B60H dissolved in different solvents, ${ }^{\circ} \mathrm{C}$

\begin{tabular}{|c|c|c|c|c|c|c|}
\hline \multirow{3}{*}{$\begin{array}{l}\text { Heating } \\
\text { rate, } \\
{ }^{\circ} \mathrm{C} / \mathrm{min}\end{array}$} & \multicolumn{6}{|c|}{$\mathrm{Tg},{ }^{\circ} \mathrm{C}$, for PVB B $60 \mathrm{H}$} \\
\hline & \multicolumn{2}{|c|}{ PVB powder } & \multicolumn{2}{|c|}{ PVB/EtOH } & \multicolumn{2}{|c|}{ PVB/2-propanol } \\
\hline & $1^{\text {st }}$ heating & $2^{\text {nd }}$ heating & $1^{\text {st }}$ heating & $2^{\text {nd }}$ heating & $1^{\text {st }}$ heating & $2^{\text {nd }}$ heating \\
\hline 5 & 58.13 & 67.02 & 51.88 & 58.47 & 41.61 & 60.60 \\
\hline 10 & 63.34 & 66.60 & 53.59 & 57.12 & 45.42 & 59.75 \\
\hline 20 & 65.32 & 68.61 & 58.09 & 61.62 & 50.96 & 57.32 \\
\hline \multicolumn{7}{|c|}{ EtOH - ethanol } \\
\hline
\end{tabular}

Table 2. Tg of PVB B75H dissolved in different solvents, ${ }^{\circ} \mathrm{C}$

\begin{tabular}{|c|c|c|c|c|c|c|}
\hline \multirow{3}{*}{$\begin{array}{l}\text { Heating } \\
\text { rate, } \\
{ }^{\circ} \mathrm{C} / \mathrm{min}\end{array}$} & \multicolumn{6}{|c|}{$\mathrm{Tg},{ }^{\circ} \mathrm{C}$, for PVB B75H } \\
\hline & \multicolumn{2}{|c|}{ PVB powder } & \multicolumn{2}{|c|}{ PVB/EtOH } & \multicolumn{2}{|c|}{ PVB/2-propanol } \\
\hline & $1^{\text {st }}$ heating & $2^{\text {nd }}$ heating & $1^{\text {st }}$ heating & $2^{\text {nd }}$ heating & $1^{\text {st }}$ heating & $2^{\text {nd }}$ heating \\
\hline 5 & 57.44 & 73.84 & 50.39 & 59.48 & 29.68 & 36.49 \\
\hline 10 & 56.59 & 73.89 & 52.70 & 64.73 & 33.25 & 36.99 \\
\hline 20 & 66.05 & 75.48 & 57.97 & 63.75 & 37.67 & 40.84 \\
\hline
\end{tabular}

PVB dissolved in ethanol has closer $T_{g}$ values taken from the first and second heating, for all the three heating rates, i.e. more reproducible and reliable results are obtained for this solvent.

\section{Microcalorimetry results}

Individual measurements were performed for the release of heat during microcalorimetry test for the nanoparticles, pure PVB, PVB dissolved in ethanol and 2-propanol, and for their mixtures.

The representative curves of the registered heat flow are shown in Fig.2, for samples with 2-propanol. The theoretical curve obtained by calculation is presented as well. Table 3 shows the calculated values of the energy for the individual materials tested and for the mixtures, and based on that calculated their relative interaction presented as D.

Comparing the theoretical and experimental curves of heat flow, the value of $\mathrm{D}$ for IF $\mathrm{WS}_{2}$ in mixture with pure PVB is closer to the value of D for PVB dissolved in ethanol, than to the value of D for 2-propanol. It may also be observed that the values of released energy are very similar for PVB powder and for PVB dissolved in ethanol, while there is a significant difference in released energy for PVB dissolved in 2propanol. Based on these observations, and on the results obtained by DSC, it may be concluded that more appropriate solvent is ethanol. Thus, further on, this solvent is used for experimental work - nanoparticles were incorporated in the system PVB/ethanol. Grade B60H was chosen for further work for its faster dissolving.

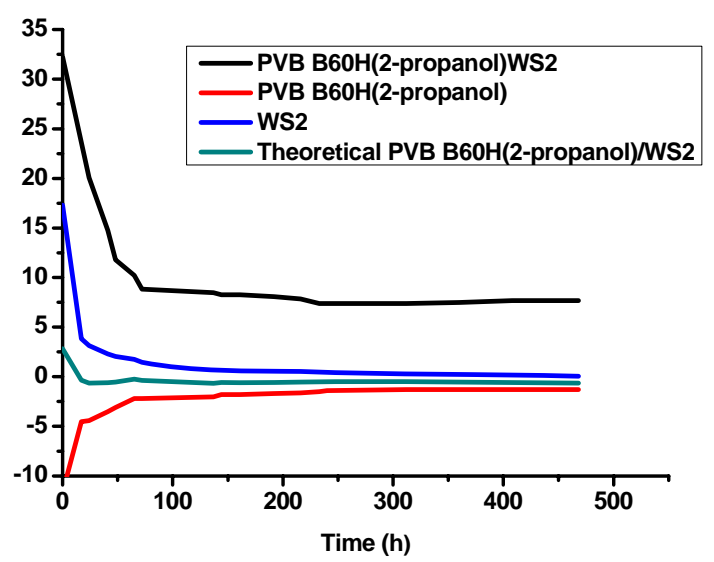

Figure 2. Heat flow curves for samples with 2-propanol

Table 3. Values of released energy - microcalorimetry results for PVB $\mathrm{B} 60 \mathrm{H} / \mathrm{IF} \mathrm{WS}$

\begin{tabular}{|c|c|c|c|}
\hline \multicolumn{2}{|r|}{ Sample } & Released energy, $\mathrm{J} / \mathrm{g}$ & Compatibility co- \\
\hline \multirow{3}{*}{1} & PVB powder & 2.78 & \multirow{3}{*}{6.13} \\
\hline & IF-WS nanoparticles $_{2}$ & 1.77 & \\
\hline & PVB/2-propanol/ IF-WS ${ }_{2}$ & 19.96 & \\
\hline \multirow{3}{*}{2} & PVB /ethanol & 2.72 & \multirow{3}{*}{8.11} \\
\hline & IF-WS ${ }_{2}$ nanoparticles & 1.77 & \\
\hline & PVB/ethanol/ IF-WS & 18.21 & \\
\hline \multirow{3}{*}{3} & PVB /2-propanol & 3.36 & \multirow{3}{*}{8.77} \\
\hline & IF-WS nanoparticles $_{2}$ & 1.77 & \\
\hline & PVB/2-propanol/ IF-WS 2 & 15.73 & \\
\hline
\end{tabular}

\section{SEM/EDS analysis results}

SEM image of a thin film nanocomposite sample, $1 \mathrm{wt} . \%$ IF-WS $2 / \mathrm{PVB} /$ EtOH, (Fig.3) shows that they are well dispersed, but still somewhat agglomerated - there may be observed nanoparticles individually dispersed in the matrix, with the occasional particles agglomerating together. The EDS spectrum in Fig. 4 confirms that the bright dots consist of $\mathrm{W}$ and $\mathrm{S}$, attributed to IF-WS $\mathrm{W}_{2}$ nanoparticles (recorded under BSE mode).

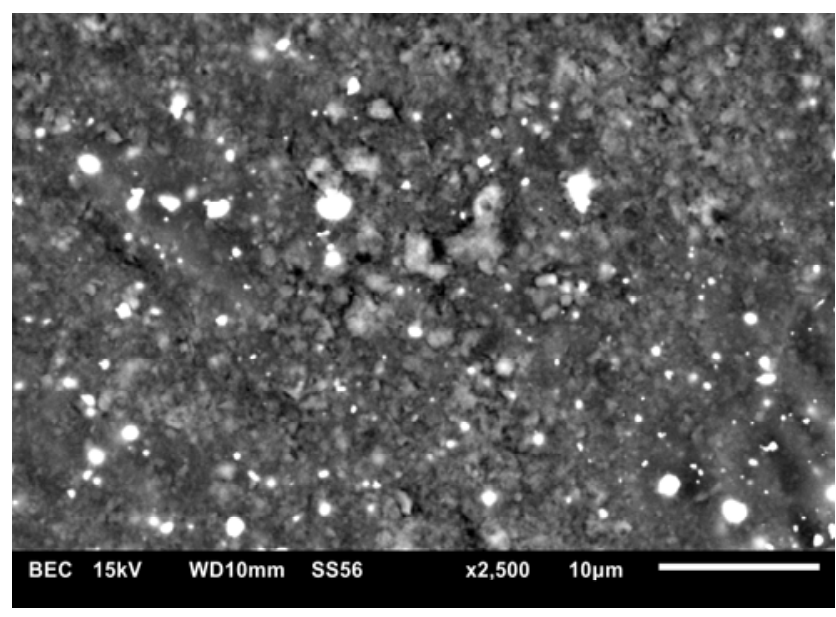

Figure 3. SEM image of $\mathrm{WS}_{2} / \mathrm{PVB} \mathrm{B} 60 \mathrm{H} / \mathrm{EtOH}$ 


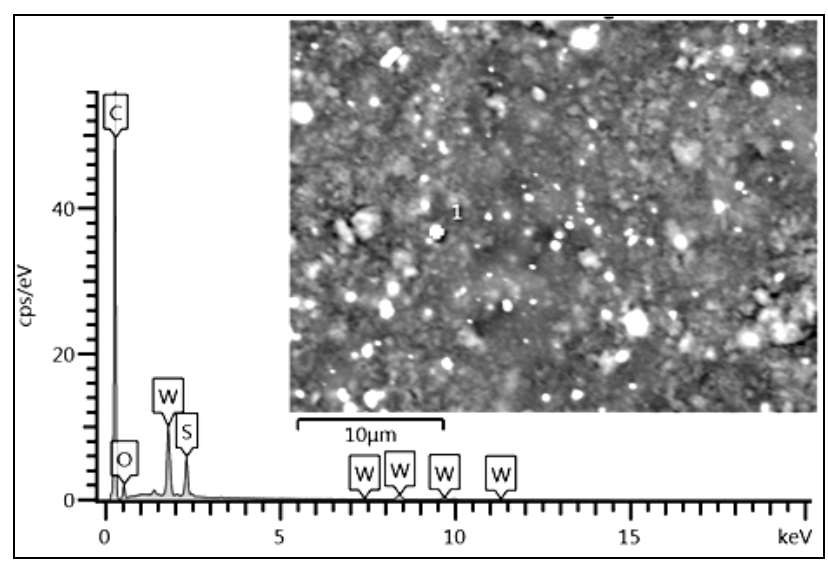

Figure 4. SEM/EDS analysis of $\mathrm{WS}_{2} / \mathrm{PVB} \mathrm{B} 60 \mathrm{H} / \mathrm{EtOH}$

EDS element mapping of the same structures showed the spatial distributions of $\mathrm{W}$ and $\mathrm{S}$ in thin film samples. These maps confirm good nanoparticles dispersion (Fig.5).

\section{DMTA results}

The results of the DMTA strain amplitude sweep test, performed at the room temperature $\left(\sim 20^{\circ} \mathrm{C}\right)$ for the analyzed samples are shown in diagrams in Fig.6. Strain sweep tests are mostly carried out for the sole purpose of determining the limit of the Linear Viscoelastic (LVE) range. As long as the strain amplitudes are still below the limiting value, $\gamma_{c}$, the curves of $G^{\prime}$ and $G^{\prime \prime}$ are remaining on a constant value, i.e. the structure of the tested sample shows no significant change at these low deformations. When measuring in the LVE range, practical users speak of "non-destructive testing". Here, the elastic behavior dominates the viscous one. Also, $G^{\prime}$ value increases with increasing $\mathrm{WS}_{2}$ content, regardless of strain amplitude level. The highest values are observed for $2 \mathrm{wt} \%$ of $\mathrm{WS}_{2}$ (Fig.6). The $\mathrm{G}^{\prime}$ value is a measure of a deformation energy stored by the polymer during the shear process, showing completely reversible deformation behavior. The increase of the $G^{\prime}$ value is connected with a reduction of polymer chain mobility, and it may be caused by the increasing the degree of cross-linking or, like here, by binderfiller interactions [14-16]. The same trend could be observed for $G^{\prime \prime}$ : increasing $G^{\prime \prime}$ value indicates an increasing portion of deformation energy which is used up already before the final breakdown of the internal structure occurs. This may occur due to relative motion between the molecules, mobile single particles, agglomerates or structures which are not linked or otherwise fixed in the network. The loss modulus represents the deformation energy which is dissipated due to inner friction processes.
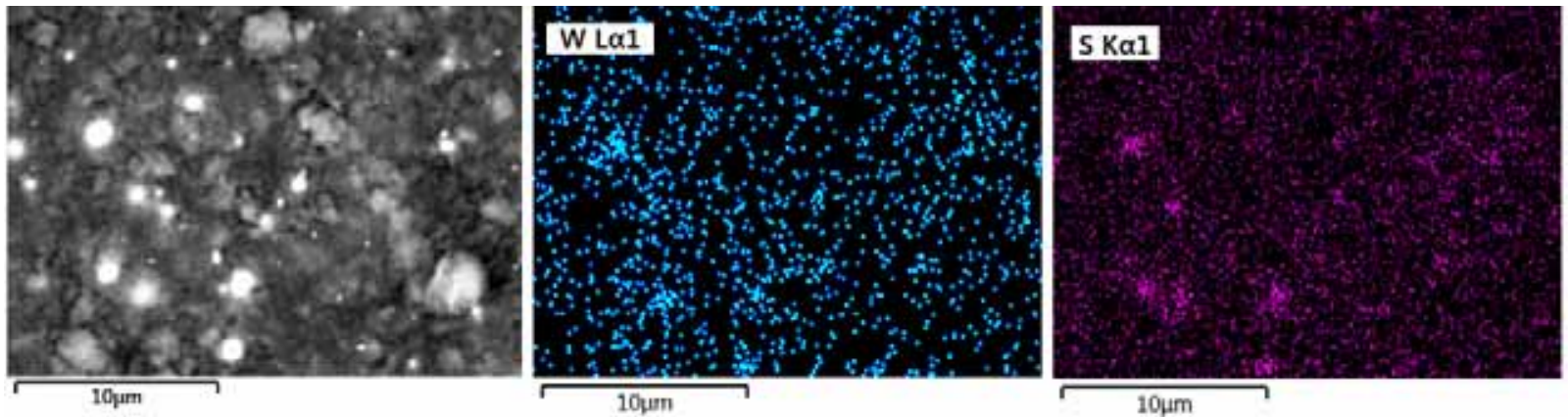

Figure 5. SEM/EDS maps of a sample PVB B60H/EtOH/1wt.\% $\mathrm{WS}_{2}$ : W and S element maps

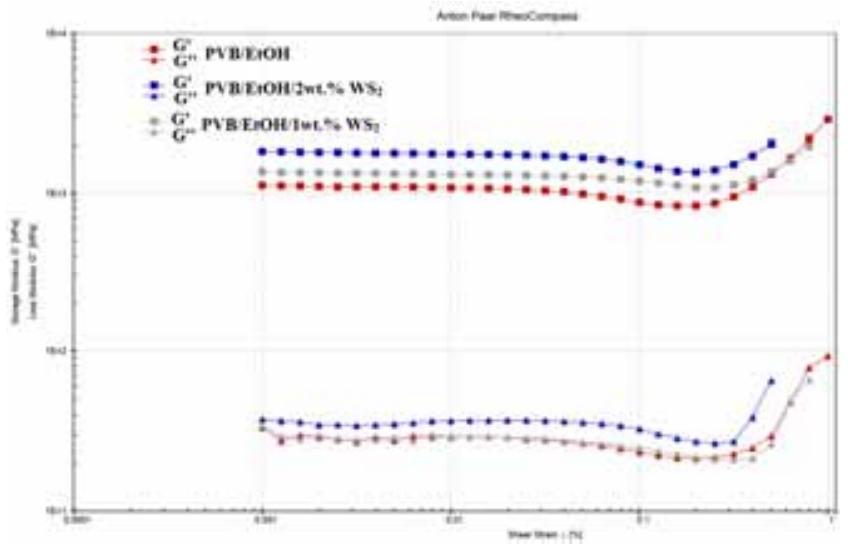

Figure 6. Amplitude sweep test: storage modulus and loss modulus dependence on shear strain

Figures 7 and 8 show DMTA data obtained in the temperature ramp tests.

In glassy state, with temperature increase, the $G^{\prime}$ values remain almost constant, while $G^{\prime \prime}$ values slightly increase. Further temperature increase causes decreasing of both modules. This is a typical behavior of this type of polymer in transition region. The reason for slow decrease of the storage modulus could be crystallinity within the polymer structure of tested samples. These curves are shifted to higher positions with the higher content of nanoparticles in the composites.
Increase of $G^{\prime}$ values is a consequence of the easier mobility of the polymer chains. The loss modulus curves reach higher peak values for higher content of nanoparticles in the composites.

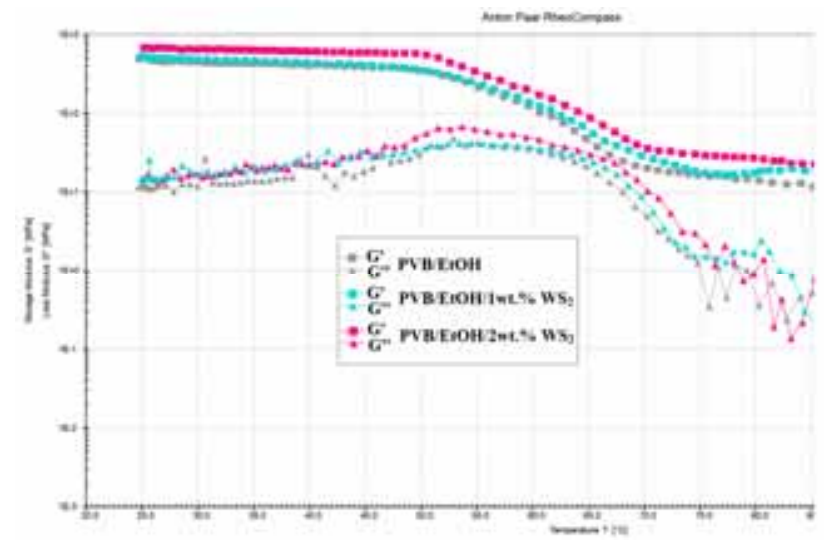

Figure 7. Temperature dependences of storage modulus and loss modulus for tested samples

The nanoparticles also caused a mild narrowing of the loss modulus peak which was attributed to the relaxation process within the composites (Fig.7). The ratio between the loss modulus and the storage modulus, called the loss factor, or tan $(\delta)$, has also higher values for the samples with nanoparticles (Fig.8 and Table 4). Higher glass transition temperatures are 
observed for the samples containing IF-WS 2 nanoparticles, so it was shown that there is an improvement of thermal properties of this kind of composite materials due to the nanofiller.

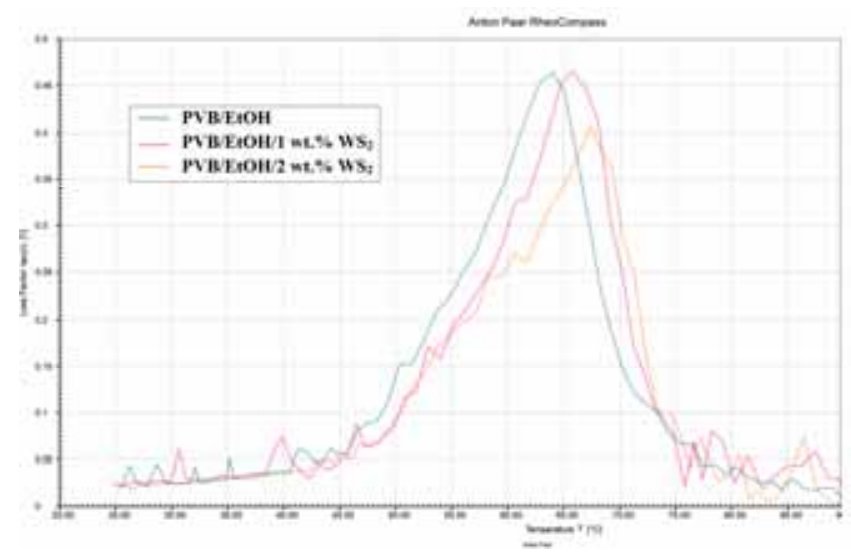

Figure 8. Temperature dependences of loss factor $\tan (\delta)$

Table $4 . T_{g}$ of the tested samples

\begin{tabular}{|c|c|c|}
\hline Sample & $\tan (\delta)_{\max }$ & $\mathrm{T}_{\mathrm{g}}\left[{ }^{\circ} \mathrm{C}\right]$ \\
\hline \hline PVB B60H/EtOH & 0.464 & 64.01 \\
\hline $\mathrm{PVB} \mathrm{B60H/EtOH} / 1$ wt.\% $\mathrm{WS}_{2}$ & 0.466 & 65.78 \\
\hline $\mathrm{PVB} \mathrm{B60H/EtOH} / 2$ wt.\% $\mathrm{WS}_{2}$ & 0.407 & 67.35 \\
\hline
\end{tabular}

A molecular interpretation of the viscoelastic behavior can be given considering the $\tan (\delta)$, which describes the molecular rearrangement regions, corresponding to the polymer fractions with different mobility. The intensity of $T_{\mathrm{g}}$, $\tan (\delta)_{\max }$, is influenced by the segmental motion of the polymer chains. The lower the mobility restrictions on the polymer chains are, the higher the $\tan (\delta)_{\max }$ values. Although the $\tan (\delta)_{\max }$ values remain almost constant with addition of 1 wt. $\%$ of the nanoparticles, 2 wt. $\%$ nanoparticle content decrease this value. Decrease of the $\tan (\delta)_{\max }$ value is a consequence of more rigid polymer structure, so one can interpret that a higher content of nanoparticles leads to reinforcing effect within the tested polymer. This could also indicate that a significant number of chain segments of polymer in this composite sample ( 2 wt.\% of IF-WS ${ }_{2}$ ) participate in this glass transition.

\section{Conclusion}

The possibility is examined to prepare poly (vinyl butyral)/tungsten disulfide nanocomposite of enhanced thermal and visco-elastic properties, i.e. to reinforce PVB by adding a small quantity of IF-WS 2 nanoparticles (1 or 2 wt.\%). It was first examined how two solvents, ethanol and 2propanol, affect thermo-mechanical behavior of different grades of PVB: Mowital $\mathrm{B} 60 \mathrm{H}$ and $\mathrm{B} 75 \mathrm{H}$. Thermal analysis on DSC at all the three different heating rates for PVB grades $\mathrm{B} 60 \mathrm{H}$ and $\mathrm{B} 75 \mathrm{H}$, resulted in more uniform $T_{g}$ values for the second heating and higher $T_{g}$ values are obtained in $2^{\text {nd }}$ heating. For the first heating, at the heating rate of $20^{\circ} \mathrm{C} / \mathrm{min}$, the highest $T_{g}$ is recorded for both solvents, for both PVB grades. PVB dissolved in ethanol has closer $T_{g}$ values taken from the first and second heating, for all the three heating rates, indicating that more reproducible and reliable results are obtained for this solvent. The curves of heat flow obtained by microcalorimetry method resulted in value of coefficient $D$ for IF $\mathrm{WS}_{2}$ in mixture with pure PVB closer to the value for PVB dissolved in ethanol, than to the value of D for 2propanol. Released energies are very similar for PVB powder and for PVB dissolved in ethanol while there is a significant difference in released energy for PVB dissolved in 2propanol, so ethanol is more appropriate solvent. Nanoparticles were incorporated in the system PVB/ethanol by solvent casting technique. SEM analysis showed good dispersion of IF-WS 2 particles and certain degree of remained agglomeration of the filler. EDS analysis and element mapping has showed good spatial distribution of IF-WS . The $^{-}$ effect of addition of IF-WS ${ }_{2}$ nanoparticles on viscoelastic properties was examined using DMTA. The storage modulus and $T_{g}$ are higher for the samples with nanoparticles due to the reinforcement effect of the particles.

The obtained results justify the usage of poly (vinyl butyral)/tungsten disulfide nanocomposite, as a material of improved mechanical properties, that might find further application in many areas.

\section{Acknowledgement}

The authors thank to the Ministry of Education, Science and Technological Development of Republic of Serbia for the financial support of the research through the projects TR 34011 and TR 34034.

\section{References}

[1] TENNE,R., MARGULIS,L., GENUT,M., HODES,G.: Polyhedral and Cylindrical Structures of Tungsten Disulfide, Nature, 1992, 360, pp. 444-446.

[2] XU,F., YAN,C., SHYNG,Y., CHANG,H., XIA,Y., ZHU,Y.: Ultratoughened nylon 12 nanocomposites reinforced with IF-WS2, Nanotechnology, 2014, 25, pp.325701-325711

[3] TEVET,O.: Mechanical and tribological properties of inorganic fullerene-like (IF) nanoparticles, Weizmann Institute of science, Rehovot, Israel, 2011.

[4] TEVET,O., VON-HUTH,P., POPOVITZ-BIRO,R., ROSENTSVEIG,R., WAGNER,H.D., TENNE,R.: Friction mechanism of individual multilayered nanoparticles, Proc. Natl. Acad. Sci. U.S.A., 20111, 108, pp.19901-19906.

[5] XU,F.: Large Scale Manufacturing of IF-WS2 Nanomaterials and Their Application in Polymer Nanocomposites, University of Exeter, Devon, UK, 2013 (https://ore.exeter.ac.uk/repository/handle/10871/8986, last date of access 2nd January 2016).

[6] NAFFAKH,M., DÍEZ-PASCUAL,A.M., MARCO,C., ELLIS,G.: Morphology and thermal properties of novel poly(phenylene sulfide) hybrid nanocomposites based on single-walled carbon nanotubes and inorganic fullerene-like IF-WS2 nanoparticles, J. Mater. Chem., 2012, 22, pp.1418-1425.

[7] HULIN LI, ZHONGWEI YIN, DAN JIANG, YAJUN HUO, YUQING CUI: Tribological behavior of hybrid PTFE/Kevlar fabric composites with nano-Si3N4 and submicron size WS2 fillers, Tribol. Int., 2014, 80, pp.172-178.

[8] ZHU,Y.Q., SEKINE,T., KIEREN,B.S., FIRTH,S., TENNE,R., ROSENTSVEIG,R., KROTO,H.W., WALTON,D.R.: Shock-Wave Resistance of WS2 Nanotubes, J. Am. Chem. Soc., 2003, 125, pp.13291330 .

[9] http://www.kuraray.eu/en/produkte/product-groups/polyvinyl-butyral/ (date of last access 12th May 2016)

[10] ISMAIL,I.N, ISHAK,Z.A.M., JAAFAR,M.F., OMAR,S., ZAINAL ABIDIN,M.F., AHMAD MARZUKI,F.: Thermo-mechanical properties of toughened phenolic resol resin, Solid State Science and Technology, 2009, Vol.17, No.1, pp.155-165.

[11] FOLGAR,F., SCOTT,B.R., WALSH,S.M., WOLBERT,J.: Thermoplastic matrix combat helmet with graphite-epoxy skin, 23rd International symposium on ballistics, Tarragona, Spain 16-20. April 2007, p.883.

[12] Anton Paar Germany GmbH, MCR: The Modular Compact Rheometer Series, 2016

[13] STANAG 4147 (Edition 2), Chemical Compability of Ammunition Componentes with Explosives (Non-Nuclear Application), June 2001.

[14] MEZGER,G.T.: The Rheology Handbook, 4th Edition, Vincentz Network, Hanover, 2014 
[15] FUENTE,De La J.L., GARCIA,M.F., CERRADA,M.L.: Viscoelastic Behavior in a Hydroxyl-Terminated Polybutadiene Gum and Its Highly Filled Composites: Effect of the Type of Filler on the Relaxation Processes. J. Appl. Polym. Sc., 2003, Vol.88, pp.1705-1712.
[16] BOHN,M.A.: Impacts on the Loss Factor Curve and Quantification of Molecular Rearrangement Regions from it in Elastomer Bonded Energetic Formulations, Energetics Science \& Technology in Central Europe, University of Maryland, 2012, pp.195-235

\title{
Preliminarna analiza mogućnosti izrade kompozita PVB/IF-WS $\mathrm{S}_{2} \mathrm{i}$ efekat dodataka nanočestica na termičko i reološko ponašanje $P V B$
}

\begin{abstract}
Ispitana je mogućnost upotrebe fulerenskih nanočestica volfram disulfida, IF-WS 2 kao punioca poli (vinil butirala), PVB, radi poboljšanja termalnih i reoloških svojstava. PVB je termoplastični polimer sa odličnim karakteristikama, široke primene: u balističkoj zaštiti, za zaštitu sigurnosnih stakala, u metalnim prajmerima i premazima, itd. U ovom istraživanju najpre su ispitane dve različite molekulske mase PVB: Mowital B60H i B75H. Rastvoreni su u različitim rastvaračima: etanol i 2propanol. Uzorci u vidu tankih filmova su pripremljeni i temperatura ostakljivanja je određena korišćenjem diferencijalne skenirajuće kalorimetrije na tri različite brzine zagrevanja $\left(5^{\circ} \mathrm{C} / \mathrm{min}, 10^{\circ} \mathrm{C} / \mathrm{min}\right.$ i $\left.20^{\circ} \mathrm{C} / \mathrm{min}\right)$. Nakon izbora optimalnog rastvarača i molekulske mase $\mathrm{PVB}$, IF-WS $\mathrm{S}_{2}$ nanočestice su dodate u rastvor PVB i ultrazvučno dispergovane. Kompatibilnost, odnosno interakcija IF-WS ${ }_{2}$ sa rastvorenim PVB je ispitana metodom mikrokalorimetrije. Deaglomeracija nanočestica $i$ disperzija u matrici PVB su analizirane pomoću skenirajućeg elektronskog mikroskopa. Efekat dodavanja IF-WS $\mathbf{S}_{2}$ na reološka svojstva odabranih uzoraka je ispitana korišćenjem dinamičko-mehaničko-termičke analize (DMTA), posmatrajući modul sačuvane energije, modul gubitaka i mehanički faktor gubitaka kao funkcije temperature za ispitne kompozite.
\end{abstract}

Ključne reči: fuleronske čestice, volfram disulfid, nanočestice, termoplastični polimeri, polivinilbutiral, kompozitni materijali, reološke osobine, termičke osobine, skanirajuća kalorimetrija, kompatibilnost.

\section{Предварительный анализ возможности подготовки композитов PVB / IF- WS 2 и эффекты влияния добавки наночастиц на термическое и реологическое поведения PVB}

\begin{abstract}
В этой работе рассматривается возможность использования неорганических наночастиц фуллереноподобного дисульфида вольфрама, IF-WS2, в качестве наполнителя в поли(винилбутирале), PVB для улучшения его термических и реологических свойств. PVB - термопластичный полимер с превосходными свойствами, широко используемый: в баллистической защите, для защиты безопасного стекла, в металлических грунтовках и покрытиях, временных связующих. Ранее в этом исследовании были рассмотрены два разных молекулярных веса PVB: Mowital B60Н и B75H. Оба сорта PVB растворяли в различных растворителях: в этаноле и в 2-пропаноле. Тонкие плёнки были получены методом литья растворителем. Температуру стеклования (Tg) исследуемых образцов определяли с использованием дифференциальной сканирующей калориметрии (DSC) при трёх различных скоростях нагрева $\left(5^{\circ} \mathrm{C} /\right.$ мин, $10^{\circ} \mathrm{C} /$ мин и $20^{\circ} \mathrm{C} /$ мин). После выбора оптимального растворителя и марки PVB наночастицы IFWS2 добавляли к растворам PVB и диспергировали ультразвуковым облучением. Совместимость, т.e. взаимодействие IF-WS2 с растворенным PVB, исследовали методом микрокалориметрии. Дисперсия и деагломерация наночастиц в матрице PVB были проанализированы с помощыю сканирующего электронного микроскопа (SEM). Эффект влияния IF-WS2 на реологические свойства выбранных образцов был исследован с использованием динамическо-механическо-термического анализа (DMTA), с учётом модуля накопления энергии, модуля потерь и коэффициента потерь в зависимости от температуры для исследуемых композитов.
\end{abstract}

Ключевые слова: фуллеронские частицы, дисульфид вольфрама, наночастицы, термопластичные полимеры, поливинилбутираль, композитные материалы, реологические свойства, термические свойства, сканирующая калориметрия, совместимость. 


\title{
Analyse préliminaire de la possibilité de préparation des composites $\mathrm{PVB} / \mathrm{IF}-\mathrm{WS}_{2}$ et effet de l'addition des nano particules sur le comportement thermique et rhéologique de PVB
}

\begin{abstract}
On a examiné la possibilité d'utilisation des nano particules fullène de bisulfure de tungstène IF-WS $\mathrm{S}_{\mathbf{2}}$ comme la charge de poly(butyral de vinyle) PBV pour améliorer ses propriétés thermiques et rhéologiques. PBV est un polymère de propriété excellentes et largement utilisé: dans la protection balistique, pour la protection des verres de sécurité, chez les amorces et les revêtements métalliques, etc. Dans cette recherche deux poids moléculaire différentes ont été examinés: Mowital B60H et B75H.Ils ont été dissous dans les solvants différents: éthanol et 2-propanol. On a préparé les échantillons sous forme de film mince et on a déterminé la température de vitrification à l'aide de calorimétrie différentielle à balayage à trois vitesse de chauffe ( $5^{\circ} \mathrm{C} / \mathrm{min}, 10^{\circ} \mathrm{C} / \mathrm{min}, 20^{\circ} \mathrm{C} / \mathrm{min}$ ). Après la sélection du solvant optimal et la masse moléculaire du PVB les nano particules IF-WS $\mathrm{S}_{2}$ ont été ajoutées dans la solution PVB et dispersées de façon ultrasonique. La compatibilité ou l'interaction de IF-WS ${ }_{2}$ avec le PVB dissous a été examinée par la méthode micro calorimétrique. La désagrégation des nano particules et la dispersion dans la matrice PVB ont été analysées par le microscope électronique à balayage. L'effet de l'addition de IF-WS sur les propriétés rhéologiques des échantillons choisis a été étudié au moyen de l'analyse dynamique mécanique thermique (DMTA ) en observant le module de stockage, le module de perte et le facteur mécanique de perte comme les fonctions de la température pour les composites testés.
\end{abstract}

Mots clés: particules fullérène, bisulfure tungstène, nano particules, polymères thermoplastiques, poly (butyral de vinyle), matériaux composites, propriétés rhéologiques, propriétés thermiques, calorimétrie à balayage, compatibilité. 